\title{
International Political Science
}

\section{A Political Scientist Returns to Vietnam}

\author{
Michael Brintnall, American Political Science Association
}

Vietnam has undergone a remarkable change since 1986 , as the nation has begun the transition from wartime leadership and confronted the shock of failing economic and social programs (Nghiep, Dinh, and Le 1993). Change is displayed to the outside world most dramatically with the economic opening, doi moi, furthered in 1989 when the centrally planned economy was scrapped for a market-oriented one (Williams 1992, 39). But there is also transformation throughout Vietnamese politics and society.

The economic, and some of the social and political, patterns of change are well documented (Price Waterhouse 1993; Williams 1992; Nghiep, Dinh, and Le 1993). Foreign investment in Vietnam is getting much attention, and there is a steady effort to rationalize the legal code and investment markets to allow this to happen. Less apparent are fitful efforts to plan for political renovation as well. The regime faces political change with obvious reluctance. As one state leader has been quoted: "We can't go back, but we're afraid of the future" (Blue 1994).

The need for an agenda of political reform is obvious. The state apparatus is still largely a product of revolutionary organization, not popular support (Williams 1992). The new 1992 constitution, while retaining communist party leadership, increased powers to state institutions and enhanced prospects for development of an independent legal system in untested ways. The 50 separate provinces, plus the 3 independent municipalities, are sometimes called 53 separate Vietnams, because each turns its sepa- rate way in spite of the obeisance to Hanoi.

There are also many internal questions driving an official agenda for study of political changeworry about socializing a postwar generation of youth into support for the regime, concern about stability in political (and economic) relations with ethnic minorities, a nascent women's movement mobilizing, among other things, to increase numbers of women elected to the National Assembly, and so forth.

Most external models for reform are singularly unhelpful. The examples of the former Soviet Union and nations of eastern Europe are discredited, because they have collapsed in a cloud of despised social disorder and because they can no longer afford to finance the travel, training, and technical assistance that used to bind Vietnam to them. China is perceived as having moved too fast toward reform (and is treated with great wariness anyway_China has been "a terror to us," is how one Vietnamese put it to me), and most of the other Asian "tigers" are disparaged as having traded too much disorder for growth.

\section{"There Is No Political Science"}

But looking inward is problematic. In the face of mounting issues for political change, and diminishing external models for response, Vietnamese officials and academics also profess that in Vietnam "there is no political science" to turn to for insight. This is not surprising. A Marxist-Leninist ideology itself is hardly conducive to development of political science as we know it in the West (Quy 1992). And an independent professoriate, exploring questions of state power and democracy, can appear to threaten the very stability that the regime hopes to find ways to maintain. Leadership in Vietnam is obsessively concerned about not losing control or encountering disorganization.

Vietnam thus faces a puzzle-an obvious need to think about political renovation, yet an absence of acceptable external models and little internal scholarship to which to turn. In the face of the twists and turns this situation has produced, a small group of officials and academics, building on a scholarly tradition of state support for literature, history, and geography (National Center 1993), has begun a program of outreach to academics internationally to discuss how to build a discipline of political science in Vietnam, and to lay groundwork for future discussions about political renovation in the nation.

The American Political Science Association, through its Committee on International Political Science, has been invited to participate in these discussions, through support provided to the Vietnamese from the Asia Foundation. In the summer of 1993 Rob Hauck and I met with Richard Blue of the Asia Foundation to plan a trip to Vietnam to explore ways for APSA to participate, and in November 1993 I traveled to Hanoi to meet with leaders of the Vietnamese social science community.

The invitation from the Vietnamese emphasized exchanging information about how political science is practiced in our countries and initiating discussions about expand- 
ing ties between U.S. political scientists and Vietnamese. I was the guest of the Vietnamese National Center for Social Sciences, talked with faculty in major universities in Hanoi, Hue, and Ho Chi Minh City, and met with officials and scholars in the government. The Vietnamese were especially interested in learning about how political science is organized in the United States, about the work of political scientists in government, in nongovernmental organizations (NGOs), in the private sector, and in academia, and about political science approaches in the United States to U.S. problems. They were not especially interested in learning about U.S. scholarship about Vietnam. They were looking instead for models for building the social science community and for defining its role in public affairs in their country. Similar visits were being arranged with scholars from eastern Europe, France, Thailand, Korea, and elsewhere.

The institutional base for social science in Vietnam, as I was introduced to it, is divided among three groups-the National Center for Social Sciences, the universities, and various government ministries. I discovered no independent association of social scientists or scholars generally. The structures I saw as an outsider on a two-week visit all pointed formally and officially to Hanoi, and more than once their attention to U.S. institutions and traditions was justified by reference to Ho Chi Minh's own interest in American political history.

\section{The National Center}

The National Center for Social Sciences is based in Hanoi with a satellite in Ho Chi Minh City. The Center is an eclectic collection of at least 16 institutes and 6 centers on ethnology, literature, archaeology, women's studies, and so forth, a well as state and law, philosophy, socioeconomic geography, and other subjects that bracket what we would call political science.

The Center has emerged from state commissions on history, geography, literature, and the like, es- tablished by the central government in the war years. It remains in some sense chartered as a central government institution. The director, Nguyen Duy Quy, is a member of the party Central Committee, and also a close scholar of the development of social science internationally (Quy 1992). The Center is financed, I gathered, largely with state funds, supplemented by outside grants such as the Asia Foundation support that paid for my trip. It appeared also to operate with greater independence than other institutions I visited, if only because there was, at the Center, a seemingly greater acknowledgment of professional norms of scholarship as well as of state service. One of the goals of the Center, I was told, was to attempt to build an endowment; there was already a sharp eye focused on contributions that might be made by international businesses seeking investment in Vietnam.

The Center's formal mission is to conduct research on historical, ethnological, cultural, and social problems with the " aim ... to provide a scientific basis for policy-making." While in many other institutions I visited such a mission could be viewed entirely through a Marxist lens, at the Center there was clearly an appreciation of an empirical base to social science. When asked the extent of academic freedom that truly existed today among scholars in Vietnam, one Center member answered "within the Center our discussions are completely frank and open; when making presentations to the highest levels of the government, though, one must be very well prepared."

The National Center, both in Hanoi and in its affiliate in Ho Chi Minh City, stood out among my visits as the site of the most active, and professionally most sophisticated, scholarship I encountered. The Center also publishes an English language journal VietnamSocial Sciences, available by subscription in the West, and at least nominally open to publication of Western manuscripts. ${ }^{1}$

The Center is working hard to cement its role at the center of social science in the country. In $\mathrm{Ha}$ noi, I was asked to make a formal talk on the subjects and organization of American political science. I felt a bit as if I were the bait the Center could use to draw the other state entities interested in social science to its building. After my trip, the Center initiated a meeting nationwide of institutes and universities interested in the social sci-

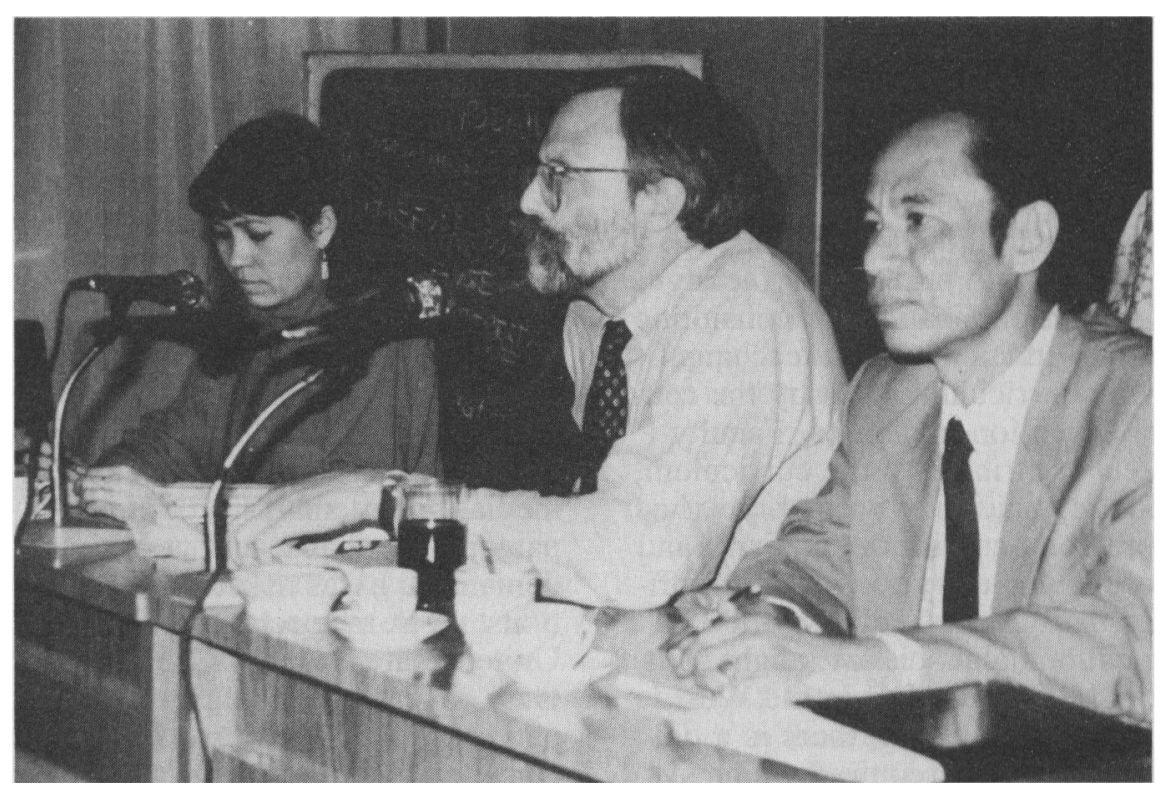

Dang Anh Phuong of the International Cooperation Department (left), Professor Nguyen Zuy Thong, Director, International Cooperation Department, National Center for Social Services of Vietnam (right), and Michael Brintnall, APSA, at colloquium with representatives of university and government social scientists, Hanoi, November 4, 1993. 


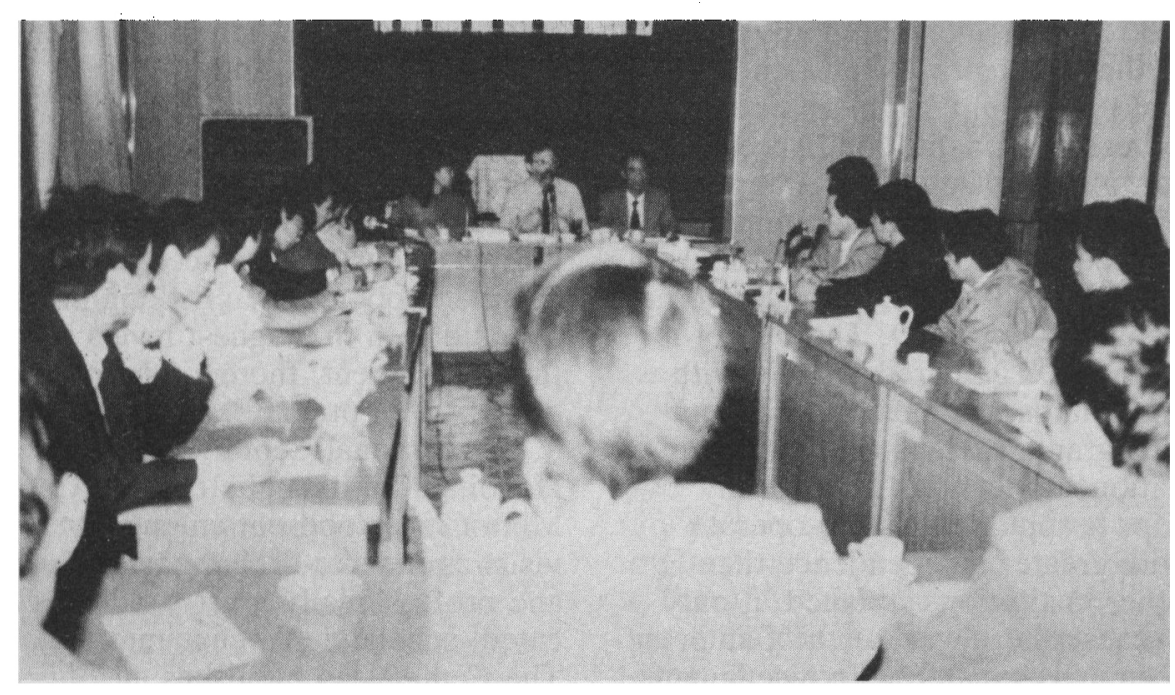

Colloquium of representatives of university and government social scientists at National Center for Social Sciences of Vietnam, November 4, 1993, at address by Michael Brintnall, APSA.

ences, to discuss plans for developing a new curriculum and research agenda in the country.

\section{Universities}

The universities were a disappointment, and unlike my meetings in the National Center and the government ministries, I found faculty doctrinaire and demoralized. At the extreme, when I asked at Hue University what they would like to see emerge from an exchange with the United States, I was told Hanoi had the most exact and reliable answer to that. There is no apparent peer accreditation system other than top-down ministry control, little evidence of faculty flexibility to adapt to student interest or needs, and no tradition of faculty research, publication, or consulting roles in addition to their teaching. ${ }^{2}$

The curriculum is set by the central education ministries. Faculty rarely contribute to the curriculum, and they said they wished they had more contact with the ministry and more opportunity to work with primary materials. There is little empirical political science taught as it would be recognized in the West. For undergraduates, there is a philosophy course required which systematically covers "all philosophy of the world." There is a political economy course which covers general themes, problems of capital- ism, and economic issues in the country; and there is coursework in scientific socialism with a focus on the "renovation process" of today-building a strong new party, combining different social classes, international relations of the communist party, government organization, and "lessons drawn from experience."

Political science is not a separate study within the universities. Relevant materials are taught as part of history, economics, law, philosophy, and sociology. There is a proposal to add political science as a new independent area of study within the university, and this might become an opportunity to begin to restructure, or at least enliven, the curriculum.

The greatest enthusiasm in my university meetings came in questions after my talk about U.S. political science (in which I laid out a simple systems model of citizen demands, party and other organizational processing, policy making, media, policy analysis, and campaigning feedback, and new citizen demands). I was asked many questions about race relations in the United States, organization of the U.S. government, political participation of youth (a worry in Vietnam), reasons slavery was not outlawed in the Declaration of Independence, the continued existence of the electoral college, and the reason for age requirements for
U.S. representatives and senators. There was evident pride in knowing something about the U.S. system, perplexity at our eccentricities, and real interest in both our successes and our failures.

The university system is in need of substantial reform. An infusion of Western-trained scholars would help, as would national attention to an accreditation system and improved resources in libraries and classrooms, a broader view of what is thought to be the role of the teacher-scholar, and greater opportunity for scholarly association.

\section{Government Ministries}

I also had interviews at several government ministries, covering training of public officials and the Ministry of Education. My scheduled visit to the political arm of the military was canceled because of the funeral of one of the senior generals, but I am told the military did participate fully in subsequent meetings convened by the Center.

The Ho Chi Minh National Political Academy trains public officials. Some 500 to 600 people per year come there to study. Within the Academy, the Institute for Political Science has a small staff of 14 members, including 8 people with doctorates earned in Vietnam and Russia, to advise in the training process and to "study the situation of the country to recommend policy." It is not clear how the latter role is meant to differ from that of the National Center.

While I was left with the impression this Academy has real influence on the workings of government, I also saw little evidence of empirical research or policy analysis. I was told of four directions to the Institute's work: construction of the ideal society; transition in economics; relations with other countries; and laws, governments, states, and citizenship. The Institute is building a library and translating political science texts from around the world. Australian student interns had just finished translating Dye and Zeigler's Irony of Democracy for them, and they proudly showed me a copy in Viet- 


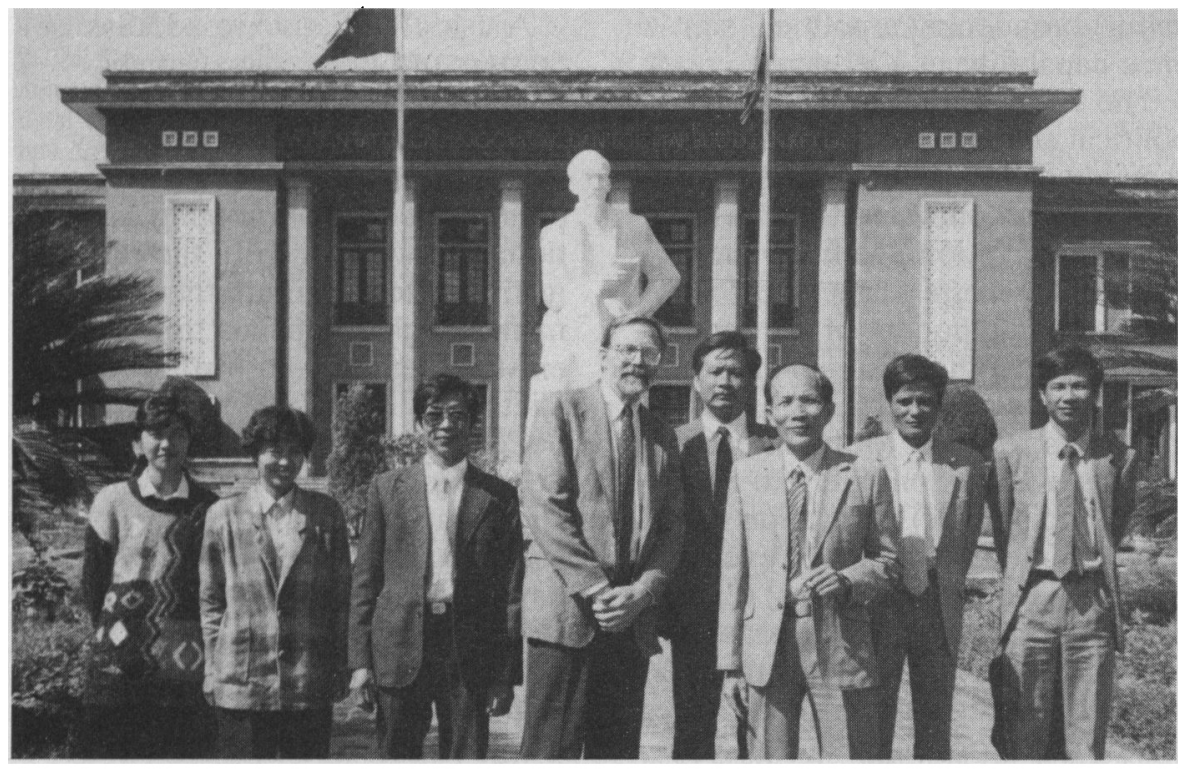

Professor Ho Van Thong, director (front right), and faculty and staff of the Institute for Political Science, Ho Chi Minh National Political Academy, Hanoi, and of the National Center for Social Sciences in Vietnam, meeting with Michael Brintnall, APSA, November 3, 1993.

namese typescript. Institute leaders complained of being very short of resources, having no computers, and not even having a fax ("you'll have to write to us," they said); lacking funds for much translating; and especially having few translators in English.

The Commission on Culture and Ideas is a component of the Central Committee, and does what they called the practice of politics, not its study. They address, they said, people's adoption of new policies such as land and tax reform; changes in politics flowing from the new market economics affecting peasants, workers, the retired, soldiers, and officials; the political ethics of high-ranking offices; methods to improve the political life of the people; and the spirit of political life.

The key practical issue that the Commission is concerned about, I was told, is that as people become more active in economic matters, they will become less active politically. The Commissioner seemed truly interested in what U.S. experience is with engaging young people in politics. Also he said there is difficulty in balancing goals such as environmental conservation in the face of peasant interest in land and lumber. The Commissioner said Vietnamese political science has more closely paralleled that studied in the communist countries because of Vietnam's past contacts there. However, he said, President Ho Chi Minh lived in Paris in the 1920s and had much experience in political science of Western countries, which sets a precedent for continuing to pay attention to Western work. He said Vietnam has not decided yet what is best in the political system, so the country is proceeding for now in the national (central, unitary government) tradition.

\section{The Political Science Agenda in Vietnam}

Political science as approached in the West was freely acknowledged by Vietnamese academics and officials I talked with as largely nonexistent in Vietnam. As one put it, political science in Vietnam is usually thought of as "how the government tells the public of its policies." However, many pieces relevant to a political science enterprise as we know it are emerging-there is for instance an active interest in the study of social problems and in the building of social accounts that is strengthening empirical tools.

Scholars I talked with are also acutely aware of political issues surrounding the place of minority communities in the country, such as the Chinese in Ho Chi Minh City and ethnic minorities in the countryside. Actions in the 1970 s that tended to drive Chinese minorities out of areas of Ho Chi Minh City had severely disruptive economic impacts, as the Chinese community had played an important mercantile and artisan role in the economy. This experience among others has increased receptivity to more sophisticated analysis of majority-minority affairs (Duong 1993).

Two other elements important to the future development of political science are its relation to the study of law, and the role that leading physical and biological scientists can play in strengthening the tradition of empirical research. The study of law is an important influence on the development of political science in Vietnam for several reasons. For one it is a useful bridge from both past eastern European influences and the Marxist tradition (Quy 1992). For another, the changes in Vietnamese law required by the economic opening are also spawning a more flexible linking of legal studies to economic and political matters. Physical science is widely respected in the nation, and many key academic leaders have Western training and linkages in these sciences. The rector at Hanoi University who led my meetings there is a Western-trained chemist with an Australian internet address on his business card. When I regretted having only Englishlanguage publications to contribute to their library, he smiled and said, "Our political science faculty will have to learn English."

\section{What Next?}

The agenda for future exchange is still being addressed. An international conference is tentatively scheduled for fall 1994 in Hanoi, subject to the vagaries of on-again, off-again support for this project within the government. Should it proceed, likely topics of discussion, and vehicles for exchange, include three issues, which stood out in my 
discussions as areas of promising future development in political science in Vietnam, though some will certainly remain sub rosa for at least a while. The three themes are improvement in public management, application of scholarship to social problems, and preparation for long-term political renovation.

Public management. Management expertise generally is recognized as a valuable, and deficient, commodity. Many cite it as the most important economic development resource (Browne 1994). There is explicit recognition that public sector improvement is needed also (Quy 1992). Training for public managers is handled by a partycontrolled academy, where I did not have the opportunity to gauge the quality of instruction.

Identifying social problems. It is clear many new issues are emerging for the country, and old ones are just beneath the surface. I found some open acknowledgment of these issues, and some denial. Examples include the situation of ethnic minorities, the social and political consequences of urbanization, and environmental protection (e.g., clearing of forested land as ethnic minorities are pushed higher into the hills by northern Vietnamese moving onto lands in the south.)

This is not peculiarly a task for political science. It is an area in which there is some initiative already underway. The task here is to assure political science concepts, emphases, and methods are incorporated into policy work, and to help bolster the whole enterprise.

Political restructuring. Political restructuring is not presently on the formal agenda, but it is bound to come because the legitimacy of the existing structure lies in the past tasks of war and unification, and because change is spawning new problems and new demands to which the existing structures cannot respond. I think in one way or another, for most of the people I met there is a sense that the economic opening is just a first step, and that political change will have to follow. This issue is the real reason for an interest in (or a worry about) broadening a political science capability in Vietnam.

The effort to introduce Western political science approaches as groundwork for debate about renovation is of course part of the politics of renovation itself. To the extent this overture to the West is seen as a component of the renovation process, then, it is likely to move in fits and starts. Substantive questions relevant to the interest in political renovation likely to lead the agenda are (1) separation of powers among legislative, executive, and judicial functions; (2) regional and provincial relations with the center government; (3) maintenance of political order in the face of economic opening; and (4) relations with and political role of ethnic minorities. Though, there will also be real interest in perspectives of theory and political philosophy underlying Western work, as the legitimacy and applicability of different political science findings are questioned.

From a two-week visit it is difficult to predict what will happen next. Virtually any activity that could enhance resources available for Vietnam will certainly get attention. Several specific strategies deserve prominent consideration. Exchanges that can help Vietnam build its academic infrastructure would be of great value. Short-term visits, in both directions, are already occurring with increasing frequency. English language training, leadership training, business training, and so forth are occurring regularly, and indications are that individuals with these experiences are moving into responsible and relevant government posts.

Training more Vietnamese in U.S. graduate institutions would be extremely valuable, though there are few Vietnamese students poised to enter U.S. graduate schools at this time. English is rapidly becoming a standard second language in Vietnam, and U.S. curriculum and research materials are greatly desired. A focused agenda on issues relating to accreditation, scholarly exchange, and association would be highly desirable, though U.S. models surely will not translate directly to the Vietnamese circumstances.
A useful initiative to address matters of public management might involve collaborating on a series of succinct papers on key topics in public administration and political science, arranging translation, and working with the relevant institutes to distribute them to Vietnamese public officials through the existing centers and institutes in Vietnam.

Collaborative work on public policy analysis is clearly relevant. Vietnam will encounter many emerging problems of urbanization, environmental protection, family structure, and so forth. The Vietnamese are unlikely to tolerate outside critiques and prescriptions. But joint scholarship, conferences, and shared resources, training, and materials are likely to be welcomed.

It is rare to have the opportunity to consider the applications of political science in such an immediate and relevant context. Further exchange with Vietnam may go forward soon, and it may not. It is heartening, nevertheless, to see officials and scholars looking to political science for answers to questions of political life. As the head of Vietnam's National Center has written:

In our country, the urgent current events in the renovation of the political system, in building and step by step perfecting the socialist democracy, amending the constitution, transforming the state apparatus, renovating the leadership of the Party, and promoting the people's right to mastership, etc. . . closely relate to the political science and that is the very practical and fundamental content which this branch of science has the task of contribution (Quy 1992, 10).

\section{Notes}

1. As of 1992 , subscriptions were US $\$ 24$ per year (including postage) and should be addressed to Vietnam-Social Sciences Quarterly, No. 27 Tran Xuan Soan Street, Hanoi, Vietnam; the account for U.S. funds at VIETCOMBANK in Hanoi is No.

37.110.996. U.S. dollars, incidentally, are currency of choice in Vietnam and are freely and widely used in everyday exchange. This same address can be used for the editorial offices, and the chief editor is Pham Xuan Nam.

2. One exception I have learned about is 
Cantho University, deep in the Mekong Delta, where the independent and entrepreneurial leadership by its rector, a microbiologist trained at the University of Michigan, has created a mostly self-sufficient institution, supported in part by specialized training programs for small businesses and by encouraging faculty consulting (Blue 1994).

\section{References}

Blue, Richard N. 1994. Talk on Asia Foundation programs in Vietnam. Washington, DC.

Browne, Maicom W. 1994. "Crowding and Managerial Gaps Imperil Vietnam." New York Times, 8 May: A1.

Duiker, William J. 1990. Vietnam Since the Fall of Saigon. Monographs in International Studies, Southeast Asia Series, No. 56A. Updated Edition. Athens, $\mathrm{OH}$ : Center for International Studies, Ohio University.

Duong, Mac. 1993. Ho Chi Minh City and the Hoa in the Process of Development. Ho Chi Minh City: National Center for Social and Human Sciences, Institute of Social Sciences.

Hung, Nguyen Manh, and Douglas Pike. 1993. Democracy in Vietnam: A Roundtable Discussion. Chicago: World without War Publications.

National Center for Social Sciences of Viet nam. 1993. Hanoi.

Nghiep, Nguyen Cong, Dinh Van Nha, and Le Hai Mo. 1993. Vietnam: The Blazing Flame of Reforms. Hanoi: Statistical Publishing House.

Quy, Nguyen Duy. 1992. "Some Ideas on Political Science." Vietnam-Social Sciences 1(31).

Rogers, David. 1994. "In the New Vietnam, Baby Boomers Strive for Fun and Money." Wall Street Journal, 7 Jan.: A1.

Stern, Lewis M. 1993. Renovating the Vietnamese Communist Party: Nguyen Van Linh and the Programme for Organizational Reform, 1987-1991. Singapore: Institute of Southeast Asian Studies.

Storey, Robert, and Daniel Robinson. 1993. Vietnam: A Travel Survival Kit. 2nd edition. Hawthorn, Victoria, Australia: Lonely Planet Publications. (This is the essential guide for travel in VietnamMAB.)

Price Waterhouse. 1993. Vietnam: A Guide for the Foreign Investor. 2nd edition. Hong Kong.

Williams, Michael C. 1992. Vietnam at the Crossroads. Chatham House Papers. London: The Royal Institute of International Affairs, Pinter Publishers.

\section{A Personal Note}

This was not my first trip to Vietnam. I was there before, in 1969, a reluctant soldier drafted from graduate school during that chasm between the deferments and the lottery. In 1969 and 1970, I spent 14 months north of Hue near the DMZ in Army artillery units, toured the Imperial City with the USO, hitchhiked down Vietnam's Route 1 to catch a flight from $D a$ Nang for $R \& R$, spent a week in Saigon sightseeing, and did many other things that seem strange to me now.

The war years are by no means exorcised, though the Vietnam War Memorial opening has settled a lot. I knew that the war experience for me was not wholly tied to the country of Vietnam itself-much that lives on rests instead with what we came back to here. So I was more curious than apprehensive about what this return would mean personally. I was assured from several people who had already been back that Americans need not fear an unwelcome reception from the Vietnamese.

I found a country that I recognized in almost every way-yet that had little connection to the place I had been. The green is the same, but the red scars of the Army bases are gone. The rice paddies still come up to the edge of the roads. Water buffalo still plow the paddies. I hadn't remembered the flotillas of puddle ducks who forage in them. I saw men cutting planks from huge logs by hand, each at one side of giant cross-cut saws, taking all day to make a board, just as I had 24 years ago. Everything is still carted on people's shoulders or bicycles (I saw one bicycle carrying two huge live hogs strapped to the handlebars)though now there is motorbike congestion in the cities, and even some auto traffic jams in Saigon.

Schoolgirls in ao dais still ride bicycles side by side, hand-in-hand, with their straight black hair down their backs. This was the same country, with an abundance of charms that had only peeked out before. I found emphatically modern and ironic touches too. Vietnam Airlines is being nicely turned out with Air France's help. I flew from Bangkok to Hanoi on Boeing 737s (which must have been leased from the French), with an in-flight magazine in both English and Vietnamese reporting on the exciting historic preservation projects in Hue, and coyly announcing that the Russian TU-something jets are quite safe. I saw the Big Apple Circus on a TV set for sale in a Hanoi "department store." Karen Carpenter music played in the background as I browsed in a Saigon bookstore, where I could have purchased the Vietnamese translation of the current Novell Netware technical manuals. The Coffee Shop of the Hotel Continental, where journalists (and I) once sat for a moment's peace in Saigon, is now an Italian pizza parlor.

Personally, I was treated warmly. When I mentioned $I$ had been in the country before in 1969, there would be brief eye contact, no discussion about the war, and resumed cordiality. There I sat in Hanoi, eating tangerines with a former North Vietnamese Army officer at whom I may once have been targeting artillery shells, commiserating about why young people don't vote.

The children looked happy-they smiled at me, and said "hello" and giggled when I said it back. I was rarely panhandled and harassed only by cyclo drivers, who wanted to help me in every way. And the food was fresh and wonderful-each morning Hanoi smells of French bread that is baked overnight and sold from every street corner.

I was transported back to 1969 only once. As I sat at a simple outdoor cafe in Hue, the bar next door suddenly blared out Creedence Clearwater songs. This had been the music of choice on my Army bases. I realized then that the missing piece for me was the noise-the helicopters, the explosions, the commotion of war, the sounds of GIs, especially the helicopters. Tourists I was sitting with had just come from a tour of the DMZ, and said their Vietnamese guide had told them, too, about the incredible, frightening, incessant noise of the war time. It may be different for each of us. But for me I am startled today by memories of the war more often when I hear the President's helicopters flying over my house in Glen Echo, Maryland, than I was by anything I saw this time back in the country.

Vietnam has a lot to do. Water is unsafe. There is virtually every disease in the world. Roads to the airport are clogged with onelane bridges. Men without arms and legs (old soldiers?) lie belly down on wheeled dollies inches above the pavement and paddle by stumps through Saigon traffic, one man I saw carrying a naked baby on his back. Dead dogs floated down the Saigon River past me.

But there is also an impressive industriousness. As I walked through Saigon, I heard sirens and saw uniformed men coming on motorcycles. These were the only serious uniforms I had seen in the country so far, and $I$ got a little worried. An old man nearby grabbed my arm, and with a toothless grin said, "The VACCINE!" As the motorcade got to me I saw it was a polio vaccination crusade, with balloons and catchy health cartoons. When the lead uniformed officer rode his motorcycle past, he shot me a big smile and a wave.

\section{About the Author}

Michael Brintnall is director of professional affairs for the American Political Science Association. He has also worked in college administration, teaching, government, consulting, and very small town politics. A current project for the U.S. Department of Housing and Urban Development involves the design and implementation of evaluation systems for local administrators of state enterprise zone programs. 